Omni-Akuatika, 13 (2) : 65-72, 2017
ISSN: 1858-3873 print / 2476-9347 online
Research Article

\title{
Thermocline Layers Depth and Thickness in Indonesian Waters when Southeast Monsoon
}

\author{
Andreas B. Lana ${ }^{1,2,}$, Nia Kurniawati ${ }^{1}$, Noir P. Purba ${ }^{2}$, Mega L. Syamsuddin ${ }^{1}$ \\ ${ }^{1}$ Fisheries and Marine Science Faculty, Padjadjaran University, West Java, Indonesia \\ ${ }^{2}$ Research Group Commitment, Fisheries and Marine Science Faculty, Padjadjaran University, West Java, \\ Indonesia \\ ‘Corresponding author: abastian36@yahoo.com
}

Received 12 May 2017; Accepted 10 November 2017; Available 28 November 2017

\begin{abstract}
Thermocline layer is effect of the unstable water when its stratified and usually with temperature decrease. This research comprehensively discussed Indonesian waters, especially at a time when ITF flows strengthened in eastern part of Indonesia as compared to the western waters of Indonesia. Therefore, it is necessary to study the changes in the depth and thickness of the thermocline in various Indonesian waters to determine the condition toward oceanographic phenomenon that occurred in Southeast Monsoon. This research used climatological secondary data which obtained from World Ocean Atlas. It is monthly temperature $\left({ }^{\circ} \mathrm{C}\right)$ monthly from year 2005 to 2012 in JuneAugust with a spatial resolution $1^{0}$. The research location is determined based on the division of zoning Regional Fisheries Management or RFM. Location research adjusted for optimize the benefits of this research in pelagic fishing effort. The method used in this research is the analysis of spatial, temporal, and literature studies about the temperature gradient changes. The result show that thermocline layer in eastern area of Indonesia found deeper than western Indonesia. Thickness of thermocline layer in western area of Indonesia has lower thickness level rather than eastern area of Indonesia.
\end{abstract}

Keywords: Thermocline, temperature gradient, south east monsoon, ITF

\section{Introduction}

Indonesia is the 'connector' between Pacific Ocean and Indian Ocean (Atmadipoera et al. 2009; Gordon et al., 2008; Susanto and Gordon 2005; Wijffels and Meyers 2004; Sprintall et al. 2002; Koch-Larrouy et al., 2008). Half via ITF other half is regional phenomenon which happens seasonally and annually (Utamy et al., 2015). Water mass movement that passes through the sea effecting the condition of thermocline layer (Gordon et al., 2000). Other factors that effected the thermocline layer in certain area are current, upwelling and downwelling, sun intensity, tide, wind, and global climate variability (Kunarso et al. 2012; Laevastu and Hela 1970; Susanto et al., 2001; Tomzack, 2000).

Thermocline layer is effect of the unstabliized water when its stratified and usually with temperature decrease. Thermocline layer is a layer where temperature rapidly decrease towards depth with temperature gradient more than $0,05^{\circ} \mathrm{C} / \mathrm{m}$ (Bureau, 1992). Depth of thermocline layer is an upper limit that separates the layers and above. The depth and thickness of the thermocline can be seen from temperature gradient of $0,05{ }^{\circ} \mathrm{C} / \mathrm{m}$ in water column (Hao et al., 2012).

There are many research about thermocline layer had been done in all over the world, especially in Indonesia, thermocline layers has been found at depth of 44,7-61,7 m and took place in Makassar strait (Yuliarinda et al., 2012), 49,7-99,4 $\mathrm{m}$ in Jayapura northern waters (Sidabutar et al., 2014), and also 63,22$69,03 \mathrm{~m}$ in southern Java (Kunarso et al., 2012), but there is no research comprehensively discussed Indonesian waters, especially at a time when ITF flows strengthened in eastern part of Indonesia as compared to the western waters of Indonesia. Therefore, it is necessary to study the changes in the depth and thickness of the thermocline in various Indonesian waters to determine the condition toward oceanographic phenomenon that occurred in Southeast (SE) Monsoon (June to August). Focus in this study is to see variability of depth layer along with thickness of thermocline layer by using vertical temperature parameter. 
The contribution of this study lies in determining the right location of fish spot especially large pelagic species. Large pelagic species, such as big eye tuna, many were caught within and below thermocline layer (Mohri and Nishida 1999; Song et al., 2006. Syamsuddin and Syamsuddin 2009). According to Tubalawony (2007), nutrients has low concentrate and fluctuate in sea surface and its concentrate will arise along with higher depth, and also will reach maximum concentration at depth of 500-1.500 m. Indonesian waters divided into 11 Regional Fisheries Management (RFM) in order to optimize fishing activities referred to FAO (Food and Agriculture Organization of The United Nations) 1995 where in numbering and division management area already according to FAO international standards.

\section{Materials and Methods}

Data used

This study discusses the condition of the thermocline by looking at the vertical temperature changes. The data used are secondary data obtained from the World Ocean Atlas (WOA) the form of climatological data. The data used is the temperature $\left({ }^{\circ} \mathrm{C}\right)$ monthly from year 2005 to 2012 in June-August with a spatial resolution $1^{0}$. Data captured includes the study area contained in Figure 1.

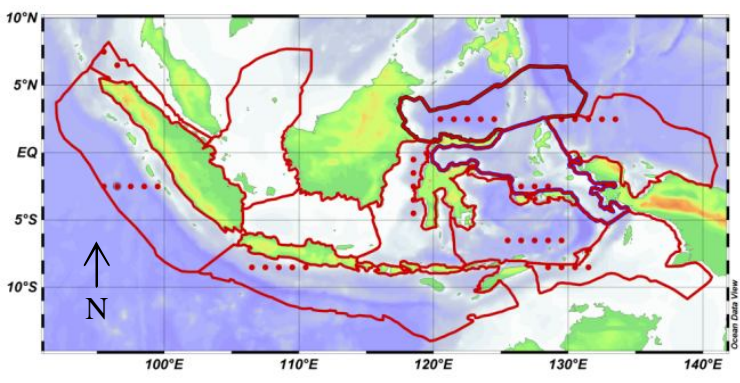

1:70.000.000

Figure 1. Location and research station

The research location is determined based on the division of zoning Regional Fisheries Management or RFM (Fig 1). Location research adjusted for optimize the benefits of this research in pelagic fishing effort. Determining the location of stations by oceanographic phenomena that occur in every region of the waters of Indonesia, especially while strengthening the ITF (eastern part) that occurred in June, July, August (JJA) to see the condition of the thermocline layer, which compared with the western part of Indonesia.

\section{Methodology}

The method used in this research is the analysis of spatial, temporal, and literature studies. Spatial analysis method includes processing secondary data spatially then interpolated using the DIVA method (Data Interpolating Variational Analysis) of the software features Ocean Data View (Troupin et al., 2013). The processed data thermocline layer that covers the depth of the upper limit, the lower limit on the thickness examine spatially and temporally.

Data interpretation temporally and spatially analyzed and compared with literature studies regarding oceanographic phenomena that occurred in the study area. Spatial interpretation used to determine differences in the spatial distribution of the upper limit of the thermocline in the study area. Formulations to find the depth of the thermocline can be seen through the determination of the temperature gradient. The calculation of the temperature gradient can be calculated using the following formula (Song et al., 2006):

$G j=\frac{T_{j+1}-T_{j}}{D_{j+1}-D_{j}}$

Annotation:

Gj = Values of vertical temperature gradient between the standard depth $D_{j}$ and $D_{j+1}$

$T_{j}=$ The temperature of water at a depth of standard

$\mathrm{D}_{\mathrm{j}}=$ Standard depth

In this case, look for the $G_{j}$ value in a column of water that is the change in temperature of $\geq 0.05^{\circ} \mathrm{C} / \mathrm{m}$ (Bureau 1992) to define the upper limit and lower limit of the thermocline layer. The upper limit of the thermocline that have been identified can indicate the depth of the thermocline in the waters. Interval between upper limit and lower limit of thermocline layer can indicate the thickness of thermocline layer.

\section{Results and Discussion}

\section{Thermocline layer condition}

Thermocline layer condition according to this research can be seen from depth, thickness, and temperature gradient value at each depth. Thermocline layer condition can be seen from depth upper limit. The thickness of thermocline layer is observed from the distance between upper limit and lower limit that have been identified by temperature gradient value. The distribution of gradient value seen on display section vertical transverse each month. Thermocline layer condition as compared with western and eastern Indonesian waters. Thermocline layer condition in western Indonesian can be seen at Fig 2. 
(a)
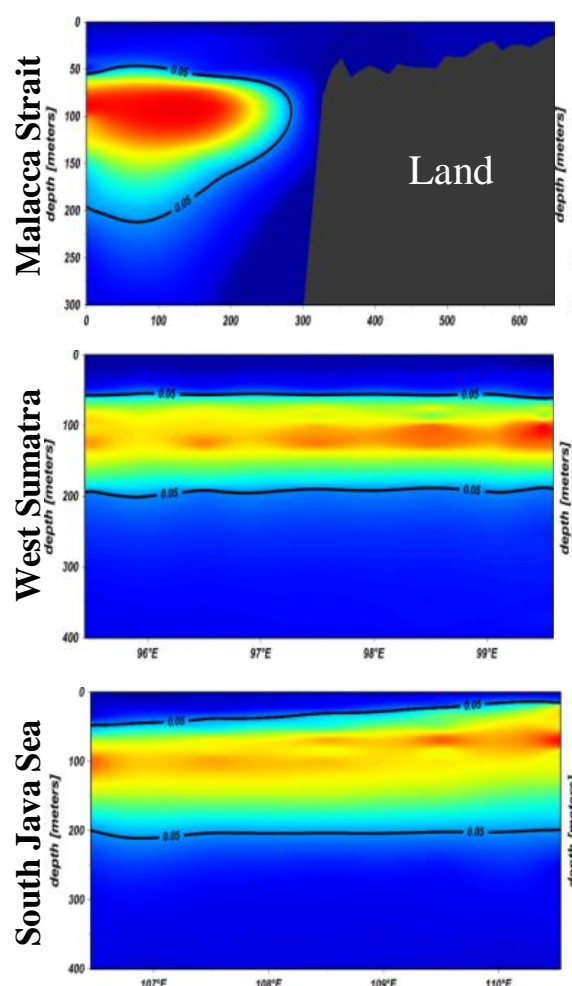

Ocean Data View

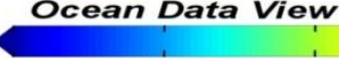

o
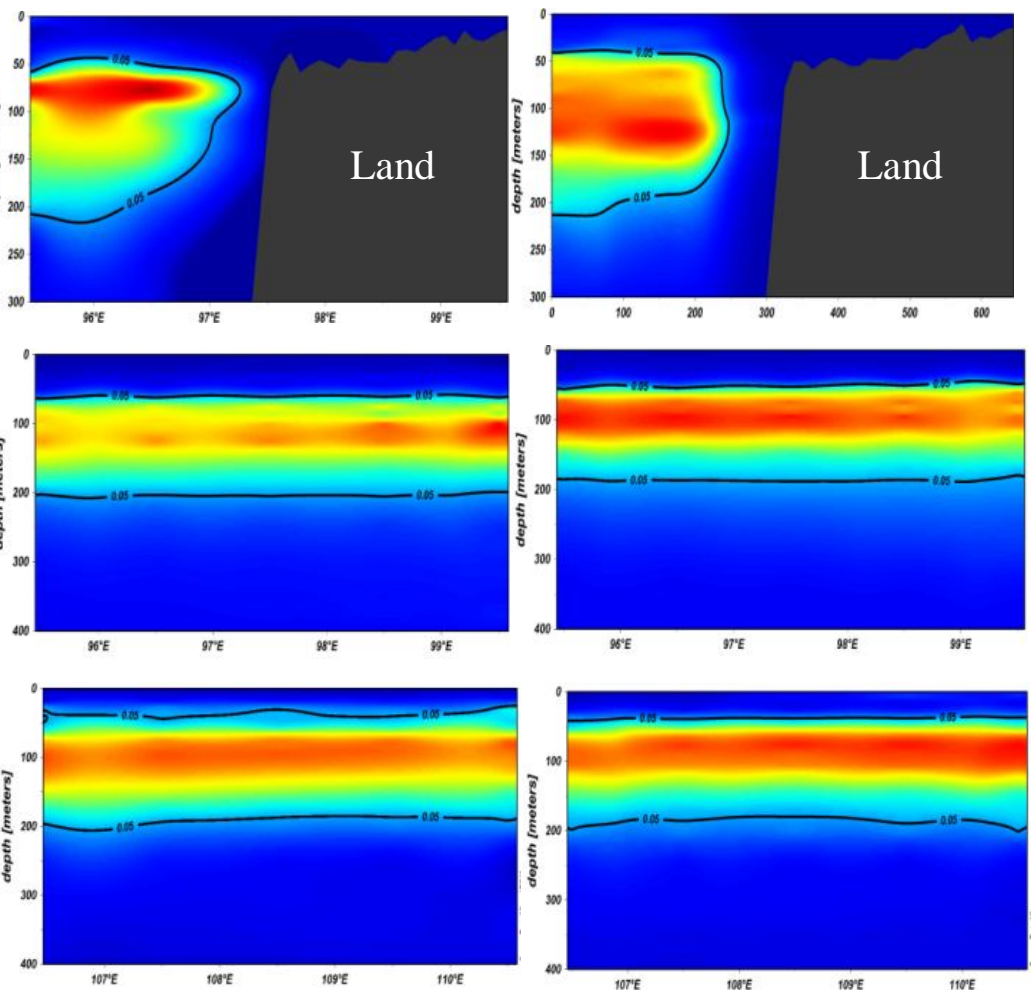

Figure 2. Thermocline Layer Condition at Western Indonesian Seas (a) June; (b) July; (c) August

Thermocline layer depth at RFM 571 shows that the increment happens in June to August with depth interval $60-45 \mathrm{~m}$. The thermocline layer shows thickening of 125- 142 as result of it become shallower. As can be seen from data result, the gradient value of SE Monsoon reach $0.25-0.3^{0} \mathrm{C}$ (Fig 2). This condition is likely affected by mass of water passing through the waters during SE Monsoon, which is colder, that there's difference in high temperature which affected the increase of gradient value. It is supported by research conducted from Ibrahim and Yanagi (2006) stating that in SE Monsoons has water mass from Andaman Sea which have low temperature and high salinity into Malacca strait.

Thermocline depth in RFM 572 is at $56 \mathrm{~m}$ depth, showing increment at depth of $61 \mathrm{~m}$ from July. Variability of thermocline layer depth in the area potentially affected by the movement of currents South Java Current. Weakened flows causes the upper limit thermocline rise to the surface. Thickness of thermocline layer on those months increased to $121 \mathrm{~m}$ (Fig 2). Increasingly thickened thermocline layer in those period is more likely influence by greater sun intensity into the waters. The sun intensity that enters the waters causes deepening thermocline layer lower limit (Kunarso et al, 2012). Temperature gradient values June to August seems to be in small range between 0.18 to $0.05^{\circ} \mathrm{C}$. The high sun intensity tend to affect to low temperature gradient in waters column.

Thermocline layer in RFM 573 arises to surface in June-July in $30 \mathrm{~m}$ depth, and reaches its peak by $27 \mathrm{~m}$ depth; meanwhile in August it reaches $35 \mathrm{~m}$ depth. When South East Monsoon occurred, South Equatorial Current splay to north over $10^{\circ} \mathrm{LS}$ and move from Sumbawa to areas along Java southern coastline and then it turns to southwest. The South East Monsoon wind causes Ekman transport moving away from southern cost of Java and caused the vacancy resulting upwelling phenomenon. The occurrence of that ephemeron impacts the increment upper limit thermocline layer as the result it become shallow. This condition affects thermocline layer thickening up to $173 \mathrm{~m}$. Gradient of the temperature shows increase of changing temperature value at each depth in JuneAugust with $\quad 0.15-0.25^{\circ} \mathrm{C}$. Upwelling phenomenon affecting gradient value is increased because lower temperature mass water will rise to the surface so that increased different temperature in water column. 
(a)
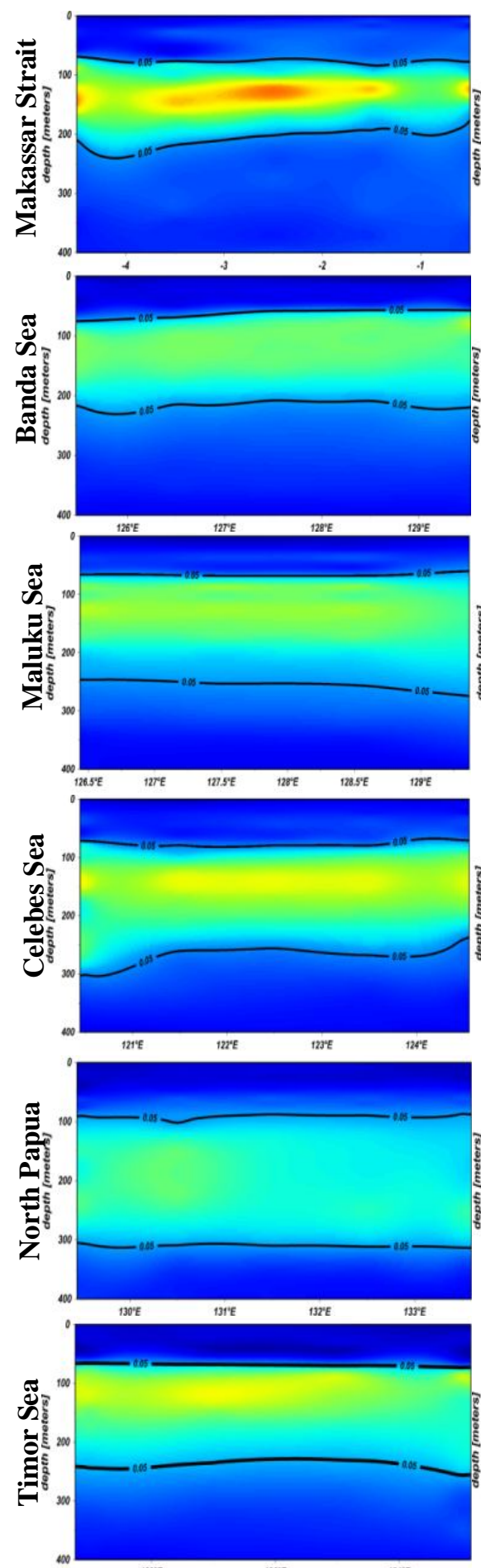

1298 (b)
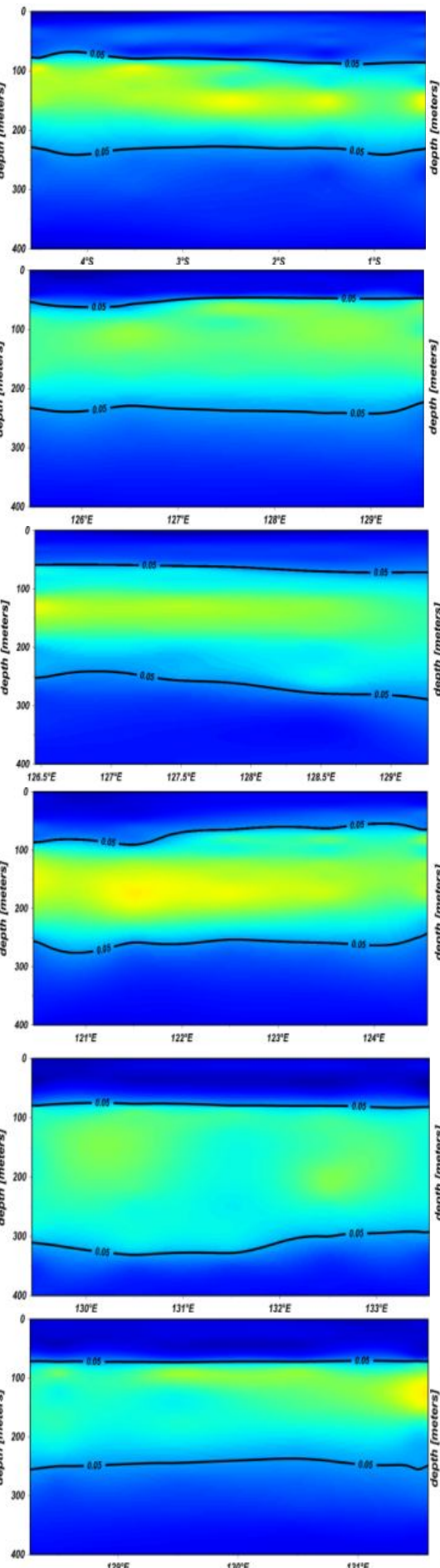

T29E
1308

Ocean Data View

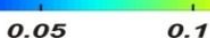

0.15

0.2

0.25

(c)
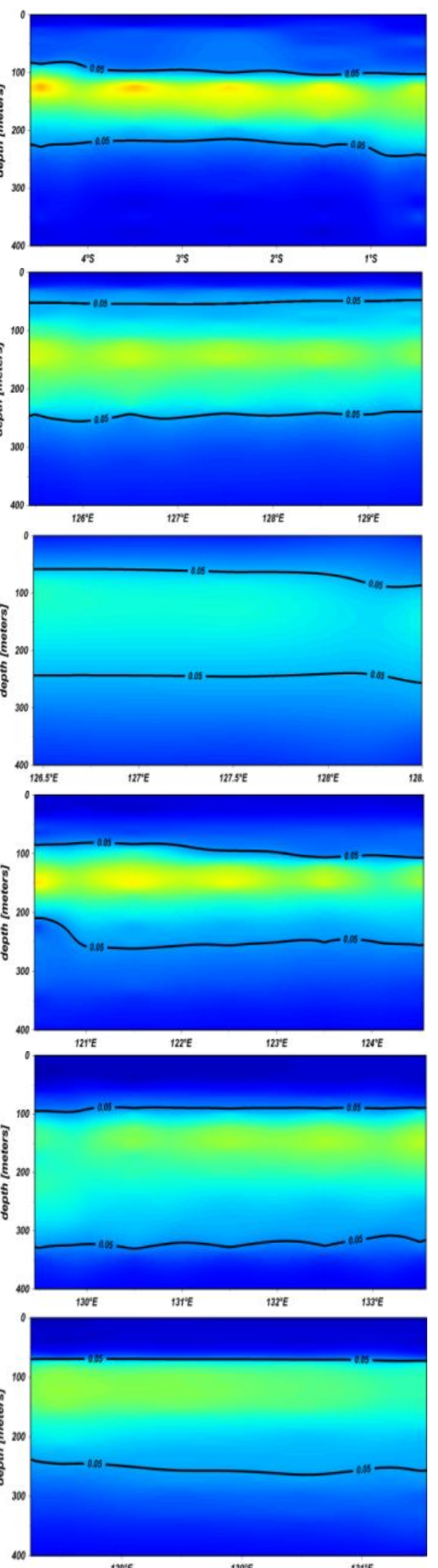

1296

$\left({ }^{0} \mathrm{C}\right)$

Figure 3. Thermocline Layer at Eastern Indonesian Seas (a) June; (b) July; (c) August

Thermocline layer in Makassar Strait has $73-104 \mathrm{~m}$ depth in June to August (Fig 3). Thickness of thermocline layer in the area gets thinner along with the superficial thermocline layers. As stated by Yuliarinda et al., (2012) increasing upper limit of thermocline layer (shallow) will cause thickness of thermocline layer tend to be thicker and vice versa. Thickness of thermocline layer in the area range between 121-135 $\mathrm{m}$. Temperature gradient values in those waters getting lower from June to August in range between 0.1$0.13^{0} \mathrm{C}$. That period is when the ITF transport strengthened bringing heat to the Indian Ocean 
that affect the temperature gradient value in the waters decreased.

Maluku Sea has deepened thermocline layer in JJA with depth of $70-82 \mathrm{~m}$. The thermocline layer in this area is thicker than Makassar strait with depth of $188-200 m$. The effects of high sun intensity on South East Monsoon cause thermocline layer in these waters thicker. As stated previously by Kunarso et al., (2012) sun intensity that enters into the waters causing a deepening of the lower limit of the thermocline layer (Kunarso et al., 2012). Temperature gradient value in this area also has small value within range $0.08-0.05^{\circ} \mathrm{C}$. The gradient in that area maybe smaller than Makassar strait, which most likely cause by mass of water that entered this area while ITF with warmer temperature that came from South Pacific Ocean is strengthen.

The depth of the thermocline in the Celebes Sea not far different, located at a depth of 85-106 m deepened in August. Thermocline layer in this area has a thickness of 144-168 m with a thermocline layer thinnest in August. Thermocline look even thinner when the depth of the thermocline layer increases. Temperature gradient value is getting smaller reached $0.1^{0}$ in August. The decline in temperature gradient value due to the stronger of ITF flows carrying heat, causing the temperature gets warmer in water column so the difference of temperature of depth is getting smaller.

Papua northern waters area found in depth of 82-99 m in JJA. In May to September a NGCC (New Guinea Coastal Current) strengthen intensively (Heron, et al., 2006) causes decrease of upper limit of thermocline layers so as thermocline layer is deeper. The current bring mass of warm water around this waters. The effect of this current also can be seen from gradient of temperature value which reduced to $0.09-0.05^{\circ} \mathrm{C}$ along with warm current movement that passes the waters. The thickness of thermocline layer in this area is thicker than other area that can reach up to $226 \mathrm{~m}$. The thickness of thermocline layer in this area potentially affects by the current variation. The current happens intensively on April to September towards Northwest (NW) (Kawabe 2008), this condition may 'pushing' lower limit of thermocline layer, so that thickness of thermocline layer increased.
The next region is the shortcut out of the ITF from Pacific Ocean to Indian Ocean, namely Timor Sea. Thermocline layer in this region identified with a depth of $75-77 \mathrm{~m}$ in JJA. Depth of thermocline layer in this area tend to be shallower in other waters which caused by decreasing of ITF transport which carrying water mass that passes through these waters. Temperature gradient value in this area also low within range $0.05-0.12^{\circ} \mathrm{C}$ and its lowest value happens in August. Thermocline layer will get thicker when thermocline layer depth rise to $193 \mathrm{~m}$ in August. Thickened thermocline layer in this area is most likely caused by deeper lower limit of thermocline layer by getting more sun intensity in SE Monsoon.

Condition of thermocline layers depth in Banda Sea has significantly different with other waters in Eastern Indonesia. The shallowest thermocline layer occurred in August found in depth of $30 \mathrm{~m}$. Thermocline layer would arise to surface in June to August with depth of 50-30 $\mathrm{m}$. Thermocline layer depth also thicken up to $205 \mathrm{~m}$ in Regional Fisheries Management 714 on this period supported by sun intensity that enters the waters. This condition will cause lower limit of thermocline layer deeper. The increased of thermocline layer in Banda Sea affects by upwelling phenomenon. The process occurred because of SE Monsoon. According to Wyrtki (1961) theory in Sediadi (2004), SE wind of SE Monsoon pushes mass of water from Banda sea and around it to the west through Flores Sea and into Java Sea so that causes vacancy mass of water in Banda Sea and upwelling phenomenon occurred. However, gradient of temperature in this area is relatively low towards SE Monsoon with value of 0.07 $0.1^{0} \mathrm{C}$. Mass of warm water that enters into the waters from Pacific Ocean (ITF) cause lower temperature gradient in the waters.

Spatial distribution thermocline depth and thickness

Thermocline layer depth in Indonesian western and eastern waters displayed spatially (Fig 4). Spatially display use to compare distribution of depth of thermocline layer in Indonesian western and eastern waters especially on South East Monsoon. 


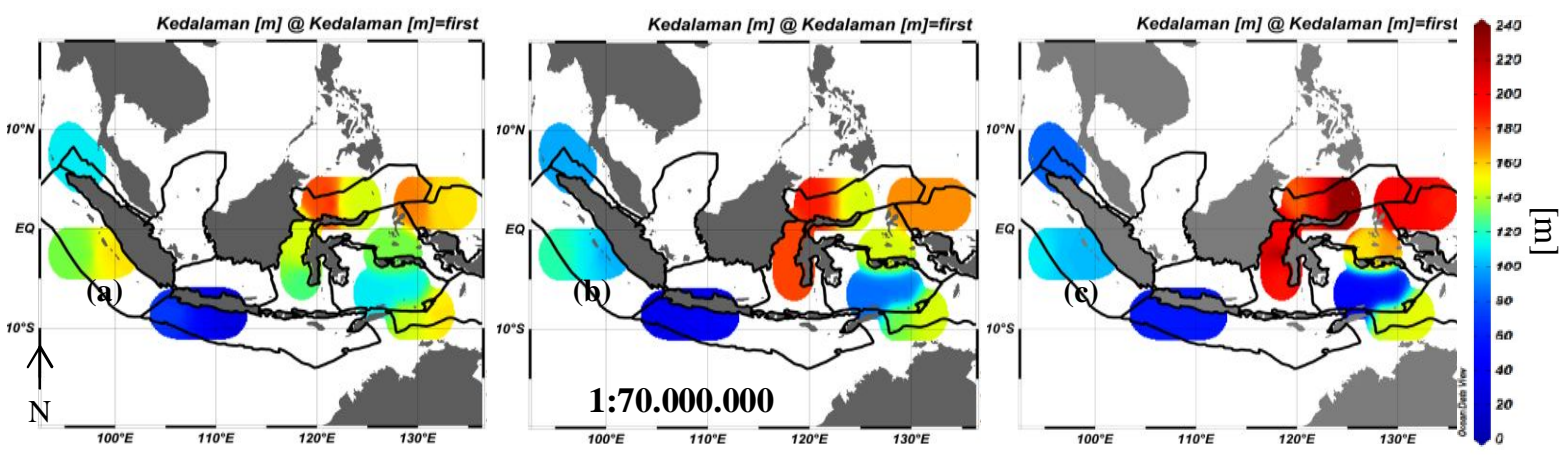

Figure 4. Spatial Distribution Thermocline Depth (a) June; (b) July; (c) August

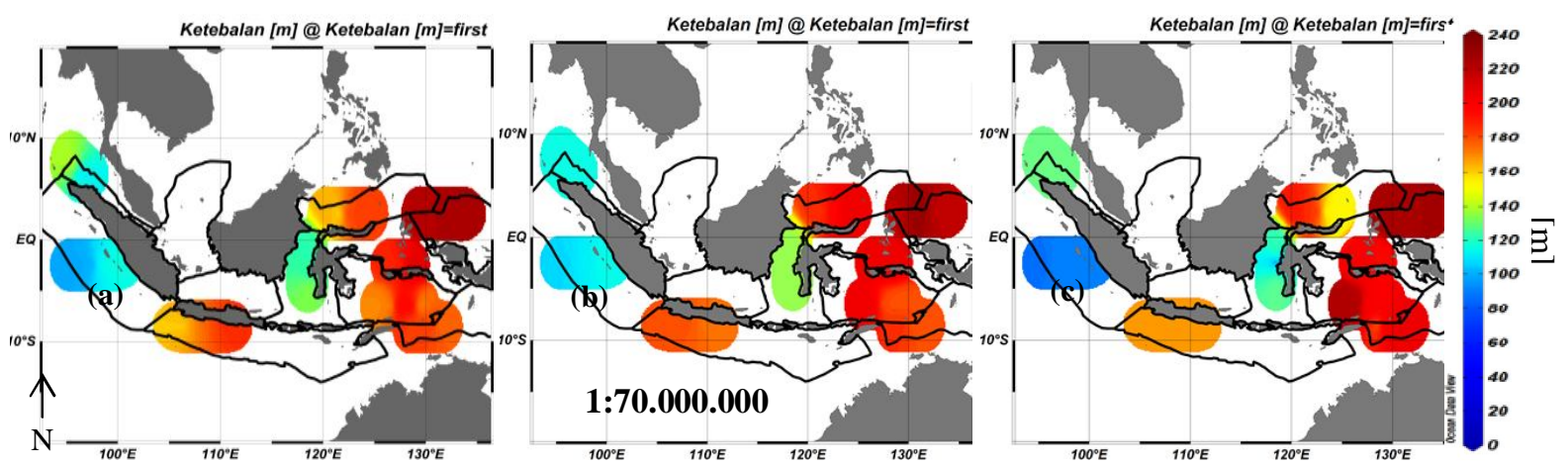

Figure 5. Spatial Distribution Thermocline Depth (a) June; (b) July; (c) August

Western area, thermocline layer found at depth of $27-61 \mathrm{~m}$ in June to August which is the shallowest in this area. Thermocline layer depth in eastern area of Indonesia found at depth of 70-106 m in June to August (Fig 4). Variability transportation volume to South that is from Pacific Ocean to Indian Ocean has high correlation which when transportation volume reach high number will cause thermocline layer pressed into deeper layers (Gordon et al., 2000). Meanwhile in Regional Fisheries Management 714 different depth of thermocline layer found at $30-40 \mathrm{~m}$ depth the result of upwelling phenomenon.

Thickness of thermocline layer in western area of Indonesia has lower thickness level rather than eastern area of Indonesia (Fig 5). Thickness of thermocline layer in western area of Indonesia gets thicker at $173 \mathrm{~m}$ depth in June to August. Thicker thermocline layer in eastern area of Indonesia dominated by red color interpolation. The thickness of thermocline layer in eastern area of Indonesia reach 174$233 \mathrm{~m}$. Highest level of thermocline layer can be found in Regional Fisheries Management 717 at August. The thickness of thermocline layer in eastern Indonesian waters is caused by heat shift transported from Pacific Ocean to Indian Ocean which is caused by decreasing lower limit of thermocline layer. This condition similar to thickened thermocline layer in one area which cause by the sun high intensity and lower limit of thermocline layer decreased. The thickness of thermocline layer in Regional Fisheries Management 713 is slightly different which happened to be thinner at depth of 121$135 \mathrm{~m}$ Sprintall et al., (2000) mentioned that in relatively short period end of May till first of June, in eastern side of Makassar strait the current will move towards north. The current stream that headed to north will be connected with arrival of Kelvin tide in Makassar trait which vines from Lombok strait at $350 \mathrm{~m}$ depth (Umangsaji 2006). Therefore, it pushed lower limit of thermocline layer and become thinner.

\section{Conclusion}

Thermocline layer in western area of Indonesia, found at depth of 27-61 $\mathrm{m}$ in June to August which is the shallowest in this area. Thermocline layer in eastern area of Indonesia found deeper than western Indonesia at depth of 70-106 m in June to August. Thickness of thermocline layer in western area of Indonesia has lower thickness level rather than eastern area of Indonesia. Thickness of thermocline layer in western area of Indonesia gets thicker at $173 \mathrm{~m}$ depth in June to August and the thickness of thermocline layer in eastern area of Indonesia reach $174-233 \mathrm{~m}$. 


\section{References}

Atmadipoera, A., Molcard, R., Madec, G., Wijfels, S., Sprintall, J., Koch-Larrouy, A., Jaya, I., Supangat, A. 2009. Characteristics and Variability of The Indonesian Throughflow Water at the Outflow Straits. Deep Sea Research I 56: 1942-1954.

Bureau. 1992. Oceanographic Survey Data Processing. In The Spesification for Oceanographic Survey (pp. 68-70). China: Standard Press of China.

FAO. 1977. South China Sea fisheries development and coordinating programme. Retrieved March 30, 2016, from FAO Web site: http://www.fao.org/docrep/field/003/ab7 40e/AB740E00.htm

FAO. 1995. Code of Conduct for Responsible Fisheries. Rome: FAO United Nations.

Gordon, A. G., A., F., K., V., Garzoli, S. L., \& Susanto, R. D. 2000. Temperature Variability within Makassar Strait. Journal Geophysics 27 (2): 237-240.

Gordon, A. L., and McClean, J. 1999. Termohaline Stratification of the Indonesian Seas-Model and Observation. Journal Geophysics 29: 198-216.

Gordon, A. L., Susanto, R. D., Ffield, A., Huber, B. A., Pranowo, W., and Wirasantosa, S. 2008. Makassar Strait Throughflow 2004 to 2006. Geophysical Research Letter 25: 1-5.

Hao, J., Chen , Y., Wang, F., \& Lin , P. 2012. Seasonal Thermocline in The China Seas and Northwestern Pacific Ocean. Journal Of Geophysical Research 117: 1-14.

Heron, S., Metzger, J., and Skirving , W. 2006. Seasonal Variation of the Ocean Surface Circulation in the Vicinity of Palau. Journal Ocean 62: 413-426.

Ibrahim, Z. Z. and Tetsuo Y. 2006. The Influence of the Andaman Sea and The South China Sea on Water Mass in the Malacca Strait. La mer 33-42.

Kawabe, M. 2008. Variability and Linkages of New Guinea Coastal Under Current and Lower Equatorial Intermediate Current Physical Oceanography 38: 1780-1793.
Koch-Larrouy, A., Madec, G., ludicone, D., Atmadipoera, A., and Molcard, R. 2008. Physical processes contributing to the water mass transformation of the Indonesian Throughflow. Journal of Ocean Dynamics doi: 10.1007/s10236008-0154-5.

Kunarso, Hadi, S., Ningsih, N. S., and Baskoro, M. S. 2012. Perubahan Kedalaman dan Ketebalan Termoklin pada Variasi Kejadian ENSO, IOD, dan Monsun di Perairan Selatan Jawa Hinga Pulau Timor. IImu Kelautan 17 (2): 87-98.

Laevastu, T., and Hela, I. 1970. Fisheries Oceanography. London: Fishing News Ltd.

Meyers, G., Balley, R. J., and Worby, A. P. 1995. Geostrophic Transport of Indonesian Througflow. Deep Sea Research 42: 1163-1174.

Mohri, M., and Nishida, T. 1999. Distribution of Bigeye Tuna and Its Relationship to The Environmental Conditions in The India $\mathrm{n}$ Ocean Based on The Japanese Longline Fisheries Information. IOTC Proceedings 2: 221-230.

Purba, N. P., and Pranowo, W. S. 2015. Pengantar Dinamika Oseanografi (1st ed.). Jatinangor, West Java: Unpad Press.

Sediadi , A. 2004. Efek Upwelling Terhadap Kelimpahan dan Distribusi Fitoplankton di Perairan Laut Banda dan Sekitarnya. Makara Sains 8 (2): 43-51.

Sidabutar, H. C., Rifai, A., and Indrayanti, E. (2014). Kajian Lapisan Termoklin di Perairan Utara Jayapura. Jurnal Oseanografi 3 (2): 135-141.

Song, L. M., Zhou, J., and Zhou, Y. Q. 2006. Evironmental Preferences of Longlining for Big Eye Tuna (Thunnus obesus) in The Tropical High Seas of The Indian Ocean. IOTC Proceeding -WPTT-14, 15.

Sprintall, J., Wijffiels, S., Chereskin, T., and Bray, N. A. 2002. Throughflow Sections in the Southeast Indian Ocean. Deep Sea Research II 49: 1363 - 1389.

Susanto, R. D., and Gordon, A. L. 2005. Velocity and Transport of the Makassar Strait Throughflow. Journal Geophysical Research 110: C01005. doi:10.1029/2004JC002425. 
Susanto, R. D., Gordon, A. L., and Zheng, Q. 2001. Upwelling Along the Coast of Java and Sumatra and Its Relation to ENSO. Geophysical Research Letters 38 (8): 1599-1602.

Sverdrup, H. V., Johnson, M. W., \& Fleming, R. H. (1946). The Oceans, Their Pysics, Chemistry, and General Biology. New York: Prentick Hill.

Syamsuddin, M. L., and Syamsuddin, F. 2009. Pengaruh Perubahan Iklim Regional Terhadap Puncak Hasil Tangkapan Ikan Tuna Mata Besar (Thunnus obesus) di Perairan Selatan Jawa dan Bali. Jurnal Kelautan Nasional 2:18-30.

Tomzack, M. 2000. An Introduction An Physical Oceanography. Australia: The Flinders University of South .

Troupin, C., Ouberdous, M., Sirjacobs, D., Alvera-Azcárate, A., Barth, A., Toussaint, M., Watelet, S., Beckers, JM. 2013. Other Implementation : Ocean Data View. In Diva User Guide (p. 124). Belgia: University of Liège.

Tubalawony, S. 2007. Kajian Klorofil-A dan Nutrien Serta Interelasinya Dengan Dinamika Massa Air di Periaran Barat Sumatra dan Selatan Jawa-Sumbawa. Disertasi, IPB, Ilmu Kelautan, Bogor.

Umangsaji, H. 2006. Variabilitas dan Karakteristik Arus Lintas Indonesia Hubungannya dengan Fluktuasi Lapisan Termoklin di Perairan Selat Makassar. Tesis, IPB, Marine Science, Bogor.

Utamy, R. M., Purba, N. P., Pranowo, W. S., and Suherman, H. 2015. The Pattern of South Equatorial Current and Primary Productivity in South Java Seas. 2015 5th International Conference on Environment Science and Biotechnology , 81.

Wijfels, S., and Meyers, G. 2004. An Intersection of Oceanic Waveguides: Variability in the Indonesian Throughflow Region. Journal of Physical Oceanography (34): 1.2321.253.

Yuliarinda, R. E., Muslim, \& Atmodjo, W. (2012). Studi Struktur Lapisan Termoklin di Perairan Selat Makasar. Journal Of Oceanography, I(1), 33-39. 